\title{
Early Silurian delta 13Corg excursions in the foreland basin of Baltica, both familiar and surprising
}

\author{
Hammarlund, Emma U.; Loydell, David K.; Nielsen, Arne T.; Schovsbo, Niels H.
}

\section{Published in:}

Palaeogeography, Palaeoclimatology, Palaeoecology - An International Journal for the Geo-Sciences

DOI:

10.1016/j.palaeo.2019.03.035

Publication date:

2019

Document version

Peer reviewed version

Document license:

CC BY-NC-ND

Citation for published version (APA):
Hammarlund, E. U., Loydell, D. K., Nielsen, A. T., \& Schovsbo, N. H. (2019). Early Silurian delta ${ }^{13} \mathrm{C}$ excursions in the foreland basin of Baltica, both familiar and surprising. Palaeogeography, Palaeoclinfarfology, Palaeoecology - An International Journal for the Geo-Sciences, 526, 126-135.

https://doi.org/10.1016/j.palaeo.2019.03.035 
1 Early Silurian $\delta^{13} \mathrm{C}_{\text {org }}$ excursions in the foreland basin of Baltica, both familiar

2 and surprising

3

4 Emma U. Hammarlund ${ }^{1,2^{*}}$, David K. Loydell ${ }^{3}$, Arne T. Nielsen ${ }^{4}$, and Niels H. Schovsbo ${ }^{5}$

5

6 Affiliations:

$7 \quad{ }^{1}$ Translational Cancer Research, Laboratory Medicine, Lund University, Medicon Village

8 404:C3, Scheelevägen 2, 22363 Lund, Sweden.

$9 \quad{ }^{2}$ Nordic Center for Earth Evolution, University of Southern Denmark, Campusvej 55, 5230

10 Odense M, Denmark.

$11{ }^{3}$ School of Earth and Environmental Sciences, University of Portsmouth, Burnaby Road,

12 Portsmouth PO1 3QL, United Kingdom.

$13{ }^{4}$ Department of Geosciences and Natural Resource Management, University of Copenhagen,

14 Øster Voldgade 10, 1350 København K, Denmark.

$15{ }^{5}$ Geological Survey of Denmark and Greenland, Øster Voldgade 10, DK-1350 Copenhagen K, 16 Denmark.

17

18 *Corresponding author e-mail: emma.hammarlund@med.lu.se

19

20 


\section{Abstract}

The Sommerodde-1 core from Bornholm, Denmark, provides a nearly continuous sedimentary archive from the Upper Ordovician through to the Wenlock Series (lower Silurian), as constrained by graptolite biostratigraphy. The cored mudstones represent a deep marine depositional setting in the foreland basin fringing Baltica and we present high-resolution data on the isotopic composition of the section's organic carbon $\left(\delta^{13} \mathrm{C}_{\mathrm{org}}\right)$. This chemostratigraphical record is correlated with previously recognized $\delta^{13} \mathrm{C}$ excursions in the Upper Ordovician-lower Silurian, including the Hirnantian positive isotope carbon excursion (HICE), the early Aeronian positive carbon isotope excursion (EACIE), and the early Sheinwoodian positive carbon isotope excursion (ESCIE). A new positive excursion of high magnitude ( 4\%o) is discovered in the Telychian Oktavites spiralis Biozone (lower Silurian) and we name it the Sommerodde Carbon Isotope Excursion (SOCIE). The SOCIE appears discernible in $\delta^{13} \mathrm{C}_{\text {carb }}$ data from Latvian and Estonian cores but it is not yet widely recognized. However, the magnitude of the excursion within the deep, marine, depositional setting, represented by the Sommerodde-1 core, suggests that the SOCIE reflects a significant event. In addition, the chemostratigraphical record of the Sommerodde- 1 core reveals the negative excursion at the transition from the Aeronian to Telychian stages (the 'Rumba low'), and suggests that the commencement of the EACIE at the base of the Demirastrites triangulatus Biozone potentially is a useful chemostratigraphical marker for the base of the Aeronian Stage.

\section{Keywords}

Chemostratigraphy, Sommerodde- 1 core, SOCIE, Oktavites spiralis Biozone, $\delta^{13} \mathrm{C}_{\mathrm{org}}$, Rumba low 


\section{Introduction}

Climate changes that affected and directed the course of early animal evolution were perhaps never more dramatic than during the Ordovician and Silurian periods, as indicated by evidence of recurring glacial deposits, sea-level changes, biotic turnover, and perturbations of the global carbon cycle (Calner, 2008; Díaz-Martínez and Grahn, 2007; Harper et al., 2014; Loydell, 2007; Melchin and Holmden, 2006; Servais et al., 2009). While changes in glacial coverage, sea-level, and biology leave both physical and chemical evidence, perturbations in the global carbon cycle are largely inferred from excursions in the isotopic composition of sedimentary carbon (Veizer, 2005). For example, our understanding of the isotopic excursions in the Silurian has developed in large part from rocks preserved in the Baltic basin and, now, a handful of discrete and geographically widespread positive excursions has been recognized (Cramer et al., 2011). However, the detailed correlation of these events and whether they accurately reflect changes in global biogeochemical conditions are ongoing debates. Indeed, it is questioned whether the sedimentary $\delta^{13} \mathrm{C}$ features record changes in open-ocean seawater or changes in diagenetic regimes (e.g. Ahm et al., 2017; Fanton and Holmden, 2007). These debates benefit from isotopic data that are well-constrained in terms of both biostratigraphy and palaeodepositional depth.

Advances in graptolite biostratigraphy have facilitated the successful identification and dating of fluctuations in the Silurian carbon isotope record. The widespread distribution of Silurian graptolites has enabled the definition of distinct and useful graptolite biozones, and a robust biostratigraphy is established (see e.g. Cramer et al., 2011; Koren' and Bjerreskov, 1997; Loydell, 1998). However, uncertainties pertaining to the biostratigraphy still remain. For example, the calibration of records between conodont-bearing and graptolite-bearing successions is often challenging because conodonts generally inhabited shallower water and graptolites generally deeper water. Only occasionally (e.g. Loydell, 1998; Loydell et al., 2003; Loydell et al., 2010) are both groups found in sufficient abundance and diversity within a single 
section to enable integration of the conodont and graptolite biozonations. Studies of biostratigraphically well-constrained Silurian successions are thus essential in order to improve interpretations of the $\delta^{13} \mathrm{C}$ record.

Depositional depth appears to influence trends in the $\delta^{13} \mathrm{C}$ record in ways that relate to either the primary chemical conditions or diagenetic changes. For example, the magnitude of Silurian global positive $\delta^{13} \mathrm{C}$ excursions declines basin-ward for reasons yet unknown (Loydell, 2007). Processes in shallow settings appear to affect the amplification, alteration, and mixing of $\delta^{13} \mathrm{C}$ trends. For example, restricted circulation (Fanton and Holmden, 2007) or diagenesis (Higgins et al., 2018) have specific impacts on the captured $\delta^{13} \mathrm{C}$. Considering that separate isotopic fingerprints may be mixed, especially in shallow settings, deep palaeodepositional sites can provide a particularly valuable record. Outboard settings were also less directly affected by eustatic sea-level changes that were common in the Ordovician and Silurian. Generally, the major sea-level changes were associated with $\delta^{13} \mathrm{C}$ excursions (Fanton and Holmden, 2007; Holmden et al., 1998; Loydell, 2007). However, deep or outboard settings are underrepresented in the rock record. Therefore, in order to decipher the causality between sea-level changes, diagenesis, and $\delta^{13} \mathrm{C}$ excursions, the deepest settings are essential since they appear to record the most significant carbon isotope events that affected open marine conditions (Loydell, 2007). Here we study the Sommerodde-1 core from Bornholm, Denmark, for which a graptolite biozonation was established by Loydell et al. (2017). The depositional site represents hemipelagic sedimentation in a deep foreland basin that was connected to the Iapetus Ocean and, thus, to the global ocean (Koren' and Bjerreskov, 1997). Our study focuses on the $\delta^{13} \mathrm{Corg}_{\mathrm{g}}$ record from the uppermost Ordovician (Hirnantian) to the Wenlock in the Silurian. In addition to several familiar carbon excursions described from other sections, the work demonstrates the presence of a previously unrecognized and significant positive carbon excursion in the Telychian Oktavites spiralis Biozone. 


\section{Geological setting}

Baltica was located at equatorial latitudes during the Silurian and large parts of the craton were flooded by a shallow epicontinental sea. However, the craton was on a collisional path with Laurentia and Avalonia, as the separating Tornquist Sea and Iapetus Ocean narrowed and eventually disappeared. In the process, peripheral foreland basins were established along the western and southern margins of Baltica and rather great thicknesses of sediment were deposited. Eventually, these foreland basins disappeared during the Caledonian Orogeny in the later parts of the Silurian and concomitantly, the Baltic epicontinental sea became increasingly restricted (Figure 1).

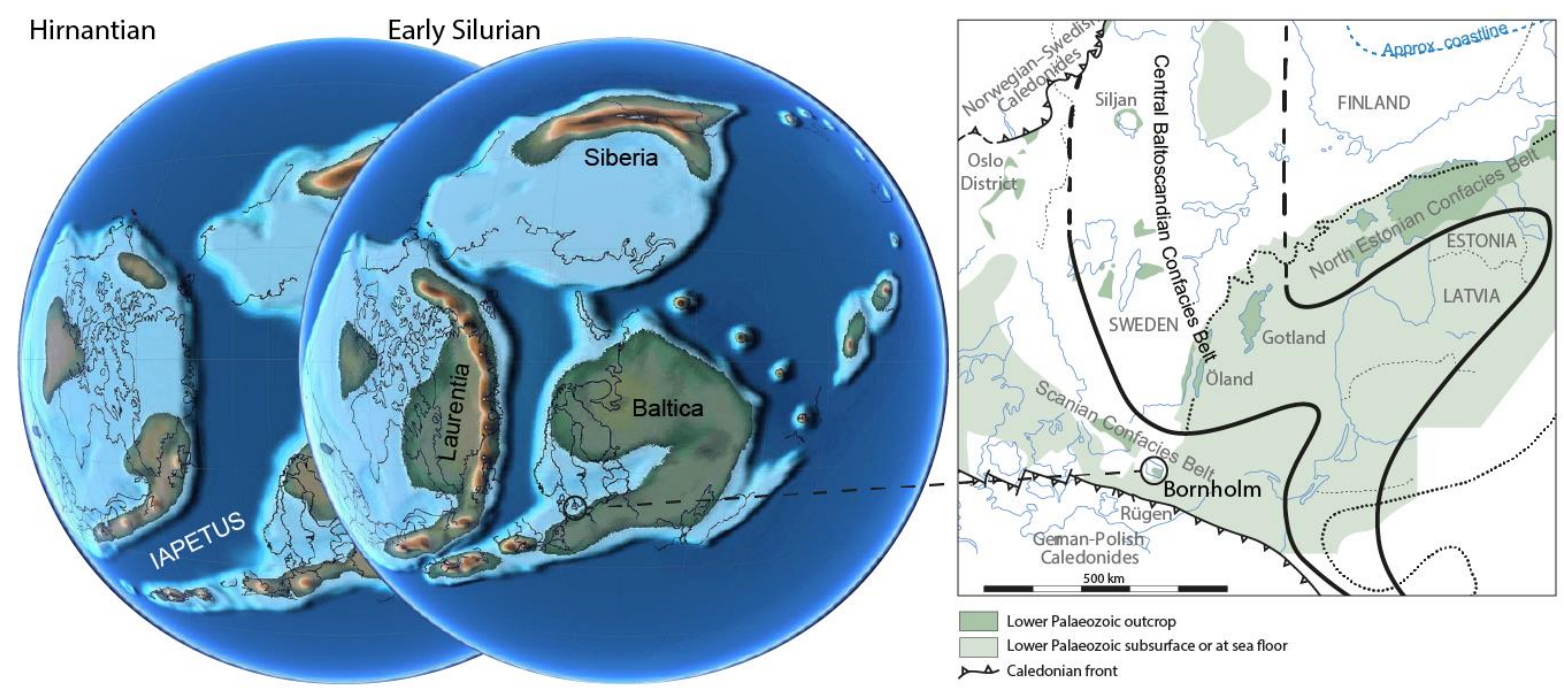

Figure 1. Palaeogeographical reconstruction showing the position of Baltica from the Late Ordovician (Hirnantian) to the early Silurian (Scotese, 2001 and personal communication), and the distribution of Lower Paleozoic strata in Scandinavia (modified from Calner et al., 2013; Nielsen, 2004; Stouge, 2004).

In the early Silurian, however, a foreland basin was still covering southernmost Scandinavia. The Silurian succession preserved in onshore Bornholm - documented almost in its entirety by the studied Sommerodde-1 core - is presumed to have been deposited in the deeper parts of this foreland basin. Depositional depth may have been $\sim 1000 \pm 300 \mathrm{~m}$ according to Bjerreskov and Jørgensen (1983), a figure based on calculations of the settling conditions of 
volcanic ash. In the area from south Sweden to north Germany (Scania-Bornholm-Rügen), the thickness of individual biozones can vary substantially as the depositional centre in the foreland basin progressively migrated northwards during the Silurian (Loydell et al., 2017; Maletz, 1997). The Silurian succession on Bornholm, $170 \mathrm{~m}$ thick in the Sommerodde-1 core, is strongly dominated by mudstones but contains common diagenetic limestone in some intervals (Bjerreskov, 1975; Koren' and Bjerreskov, 1997; Schovsbo et al., 2016). The basin appears to have been fairly open during the studied time interval, which is evidenced by the presence of geographically widespread graptolites (recognized e.g. in the studied core) and conodont taxa (recognized e.g. on Gotland) (Cramer et al., 2011 and references therein).

Traditionally, the Silurian shales on Bornholm have been assigned to the Rastrites and Cyrtograptus shales, but there is no well-defined boundary between these units; overall the Rastrites shale tends to be darker grey and the Cyrtograptus shale tends to be lighter grey. The stratigraphy of the Silurian shales in onshore Bornholm has been discussed by Bjerreskov (1975), Koren' and Bjerreskov (1997), and Loydell et al. (2017); for older references, see these papers. The investigated succession straddles the Hirnantian (Upper Ordovician) through the Rhuddanian, Aeronian, Telychian and Sheinwoodian (all lower Silurian). The succession was deeply buried in the late Silurian-Early Devonian and the thermal maturity is about $2.3 \% \mathrm{R}_{0}$ (Petersen et al., 2013).

\section{Material and methods}

The core interval 7.5-197.2 $\mathrm{m}$ in the Sommerodde-1 core (DGU 248.62), southern Bornholm, was sampled with an average spacing of $0.78 \mathrm{~m}$; for details of the location of the drill site, see Loydell et al. (2017). The samples were crushed at GEUS in an agate swing mill to below 250 micrometres. Isotope analyses of organic carbon were performed at the Nordic Center for Earth Evolution, University of Southern Denmark, by isotope ratio mass 
spectrometry (Thermo Delta V plus) after combustion in an elemental analyser Flash EA 2000.

For calibration of C isotope determinations, international standards of sediment (IVA 33802151

140 with $\delta^{13} \mathrm{CVPDB}_{\text {VPB }}-26.07 \%$ ), protein (IVA 33802155 with $\delta^{13} \mathrm{C}_{\text {VPDB }}-26.98 \%$ ), and urea (IVA

14133802174 with $\delta^{13} \mathrm{C}_{\mathrm{VPDB}}-45.38 \%$ o) were used. The isotopic composition of carbon $\left(\delta^{13} \mathrm{C}\right)$ is

142 reported as relative to the Vienna Pee Dee Belemnite (VPDB), with a precision of $0.1 \%$. The

143 data is reported in Figures 3-7 where the scale varies $\left(\delta^{13} \mathrm{CVPDB}_{\mathrm{VP}}\right)$ but vertical gridlines are set at 144 a distance of $2 \%$.

145

146

147

148

149

150

151

152

153

154

155

156

\section{Results}

A total of 297 new $\delta^{13} \mathrm{C}_{\text {org }}$ data points was generated for this study (Appendix A). The analyzed samples derive from an interval straddling the Hirnantian (Upper Ordovician) to the Sheinwoodian (lower Silurian) and the data are shown in Figure 2. Samples from the Sommerodde- 1 core have a mean of $-29.4 \%$ and a standard deviation of $1.25 \%$. Values significantly higher (+1 s.d.) than the average (over $-28.2 \%$ ) are found in the Hirnantian, the Telychian, and the Sheinwoodian, while significantly lower (-1 s.d.) values (below $-30.7 \%$ o) are found at the transition between the Aeronian and the Telychian (see grey shadings in Figure 2). Additionally, a modest positive excursion of $\sim 1 \% \delta^{13} \mathrm{C}_{\text {org }}$ values compared to values in samples immediately below and above, is recognized in the lower Aeronian and a small positive shift is seen in the middle Rhuddanian. The results are further presented in Figures 3-7 and discussed in detail below. 


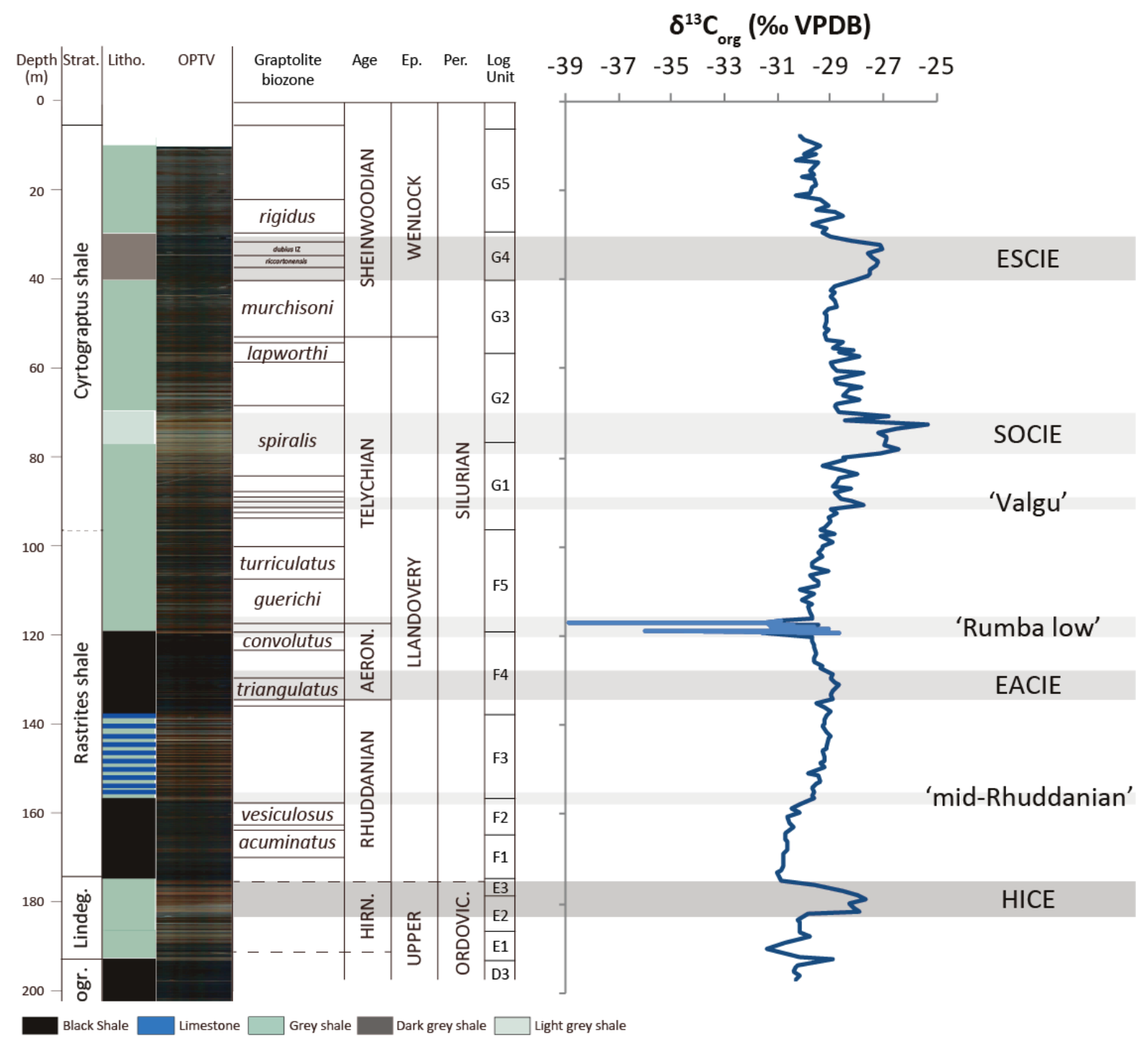

Figure 2. A log of the Sommerodde-1 well with depth, stratigraphy (strat.), lithology (litho.), optic televiewer (OPTV), graptolite biozones, Age, Epoch (Ep), Period (Per), log units, and the $\delta^{13} \mathrm{C}_{\text {org }}$ data through the succession. Shaded bands highlight features in the data that we discuss: three are previously recognized excursions (dark grey) - the Hirnantian isotopic carbon excursion (HICE), the early Aeronian carbon isotope excursion (EACIE) and the early Sheinwoodian carbon isotope excursion (ESCIE). Other excursions (light grey bands) are new, negative or less well-recognized. For the 'midRhuddanian' excursion only the onset of the excursion is shaded. For values in the interval with highresolution sampling (light blue line), see SI data. Scale ranges from -25 to $-39 \%$. Lithology, OPTV, and $\log$ units from Schovsbo et al. (2015) and biozones from Loydell et al. (2017). 


\section{Discussion}

The following features can be recognized in the $\delta^{13} \mathrm{C}_{\mathrm{org}}$ record measured in the Sommerodde- 1 core, discussed in ascending order. We define an excursion to range between the first and last sample that has higher $\delta^{13} \mathrm{C}_{\text {org }}$ values than baseline values of that interval.

\subsection{The HICE}

The Hirnantian positive isotope carbon excursion (HICE), observed globally, is recognized in the Sommerodde-1 core in the interval from $182.47 \mathrm{~m}$ to $175.96 \mathrm{~m}$ (Figure 2). This interval comprises most of the Lindegård Formation, which, in another core from Bornholm (Billegrav-2), has been determined to belong to the Metabolograptus persculptus Biozone in the Upper Ordovician Hirnantian Stage (Hammarlund et al., 2012). In the Sommerodde-1 core, the HICE has an amplitude of $\sim 3 \%$.

\subsection{The mid-Rhuddanian positive shift in $\delta^{13} C_{\text {org }}$}

The Sommerodde- 1 data exhibit a small, positive shift in $\delta^{13} \mathrm{C}_{\text {org }}$ values at the transition between $\log$ units F2 and F3 at 156.9 m (Figure 3). No distinct excursion is discernible and the shift is small. However, the very distinctive alternating dark grey and pale grey carbonate cemented mudstones of log unit F3 (Loydell et al., 2017, fig 3) were shown by Koren' and Bjerreskov (1997) to have their base within the lower part of the Cystograptus vesiculosus Biozone in which a positive excursion is observed elsewhere (e.g. Melchin and Holmden, 2006). A minor shift is observed in the deep-water successions of Dob's Linn, Scotland (Underwood et al., 1997) and at Cape Phillips South on Anticosti Island in Canada (Melchin and Holmden, 2006). Correspondingly, a minor positive $\delta^{13} \mathrm{C}_{\mathrm{org}}$ excursion of mid-Rhuddanian age is recognized in the E1-NC174 core of the Murzuq Basin in Libya (Loydell et al., 2013). Also, the rising limb of what is considered to be the same excursion is present in the BG-14 core from southern Jordan (Armstrong et al., 2009; Armstrong et al., 2005; Loydell et al., 2009). 


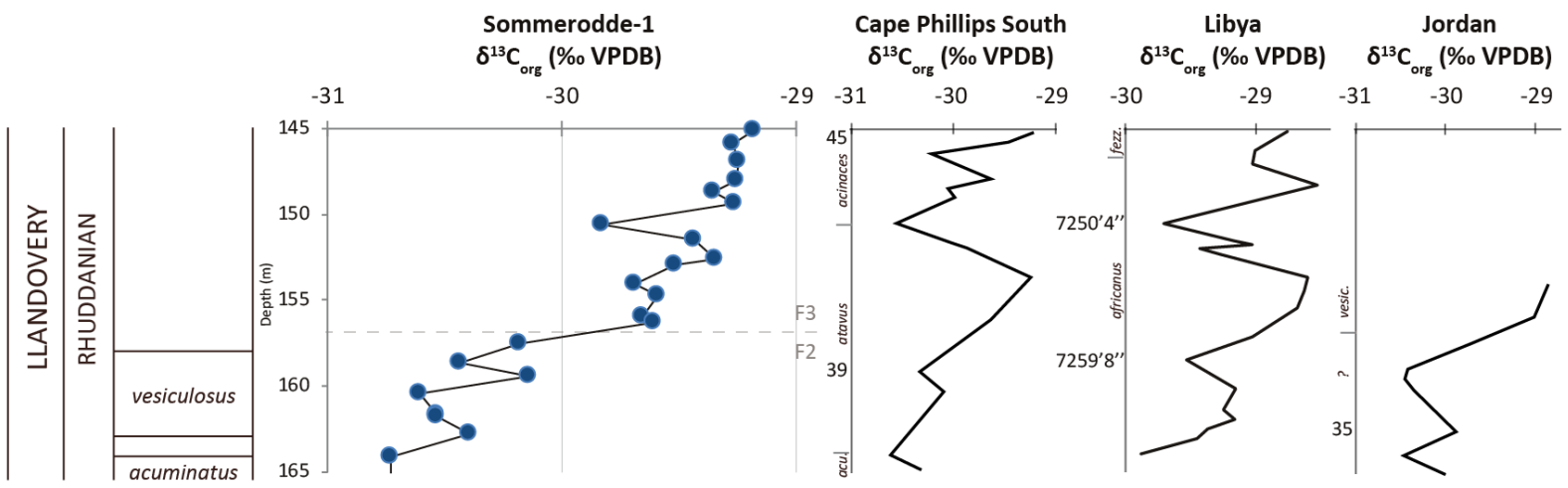

Figure 3. The onset of the positive carbon isotope excursion in the mid-Rhuddanian in the Sommerodde-

1 core (this study), correlated to carbon isotope data described in the section at Cape Phillips South in

Canada (Melchin and Holmden, 2006), the Libyan core E1-NC174 (Loydell et al., 2013) and in the Jordanian core BG-14 (Loydell et al., 2009). Scale for the Sommerodde-1 data ranges from -29 to -31 \%. For log units (F2-F3), see Schovsbo et al 2015 and Figure 2.

The correlation between these areas relies on detailed graptolite biostratigraphy, to which we can relate the Sommerodde-1 data. The Libyan core (E1-NC174) contains a largely endemic graptolite fauna (Loydell, 2012), whereas the Jordanian core (BG-14) yielded a mixture of

North African and Arabian endemics as well as more widespread taxa that enabled application of the 'standard' graptolite biozonation by Loydell et al. (2009). In the Jordanian core, the minor positive shift in $\delta^{13} \mathrm{C}_{\text {org }}$ values occurs in strata lacking diagnostic graptolites but that overlie beds containing an upper Akidograptus ascensus-Parakidograptus acuminatus Biozone assemblage and underlie beds containing a Cystograptus vesiculosus Biozone graptolite assemblage. In the lowest assemblage assignable to the $C$. vesiculosus Biozone in the Jordanian BG-14 core (at a depth of $30.0 \mathrm{~m}$ ), Dimorphograptus confertus is present. However, D. confertus occurs in the middle and upper parts of the C. vesiculosus Biozone elsewhere (Koren' and Bjerreskov, 1997; Štorch, 1994a). Thus, the presence of D. confertus in immediately overlying strata strongly suggests that the rise in $\delta^{13} \mathrm{C}_{\text {org }}$ values (between $30.9 \mathrm{~m}$ and $30.0 \mathrm{~m}$ in the BG-14 core) is within the C. vesiculosus Biozone. 
Taken together, it seems likely that the positive $\delta^{13} \mathrm{C}_{\text {org }}$ shift seen between log units F2 and

213

214

215

F3 in the Sommerodde-1 core correlates with a similar shift seen in in a handful of sections around the world, and that the onset of this minor excursion commenced in the lower part of the $C$. vesiculosus Biozone.

\subsection{The early Aeronian positive excursion (EACIE)}

In the Sommerodde- 1 core, a positive $\delta^{13} \mathrm{C}$ excursion of $\sim 0.8 \%$ is observed at the transition from the Rhuddanian to the Aeronian between $133.93 \mathrm{~m}$ and $126.55 \mathrm{~m}$ (Figure 4).

The excursion starts at the base of the Demirastrites triangulatus Biozone (at $133.93 \mathrm{~m}$ ). The uppermost sample of the excursion (at $126.55 \mathrm{~m}$ ) is from an interval lacking diagnostic index fossils, but which lies above the highest confidently assigned Demirastrites triangulatus Biozone sample (at $129.80 \mathrm{~m}$ ) and below the lowest definite Pribylograptus leptotheca Biozone sample (at $126.75 \mathrm{~m}$ ). Within this interval, the graptolite Demirastrites pectinatus occurs (in the 128.11-128.13 m sample), which has been shown recently to be restricted to the $D$. pectinatus and lowermost Demirastrites simulans biozones that overlie the $D$. triangulatus Biozone (Štorch et al., 2018). Hence, D. pectinatus constrains the end of the excursion to be somewhere within the $D$. pectinatus and lowermost $D$. simulans biozones.
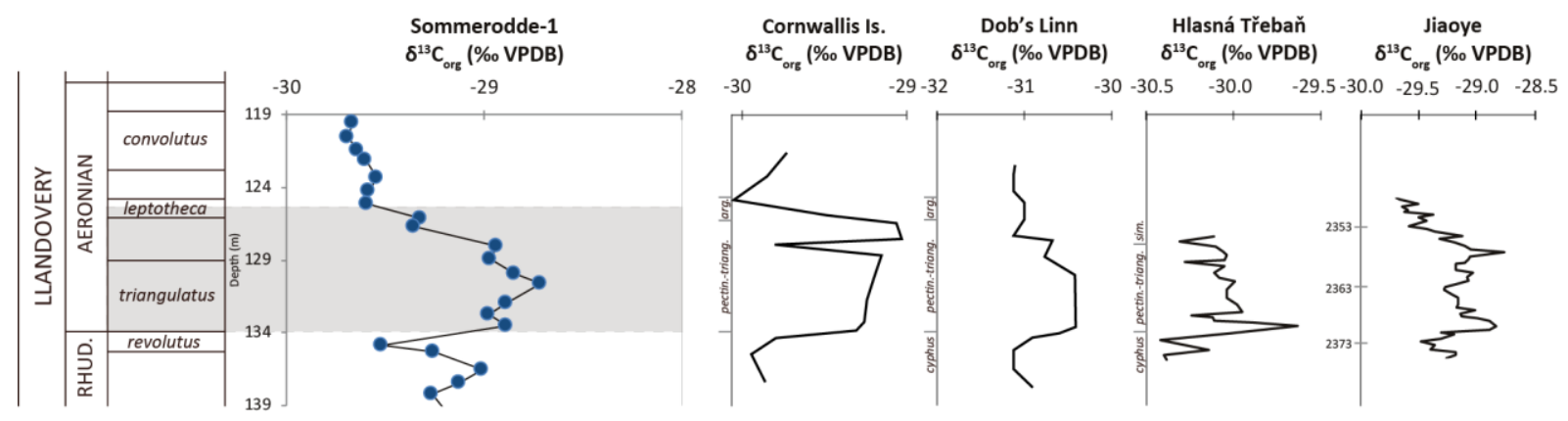

Figure 4. The positive early Aeronian carbon isotope excursion (EACIE) in the Sommerodde-1 core (this study), correlated to carbon isotope data described in the sections at Cornwallis Island in Canada (Melchin and Holmden, 2006), Dob's Linn in Scotland (Melchin and Holmden, 2006), Hlasná Třebaň 
in the Czech Republic (Štorch et al., 2018), and in the Jiaoye core from the Yangtze platform, China (Liu et al., 2017). Scale for the Sommerodde-1 data ranges from -28 to $-32 \%$.

The EACIE is of small magnitude, but widely recognized, as shown first by Melchin and Holmden (2006) and subsequently by others, e.g. Cramer et al. (2011) and Melchin et al. (2012). The excursion is noted in at least two other deep-water successions, at Dob's Linn, Scotland, and Cape Manning, Arctic Canada (Heath, 1998; Melchin and Holmden, 2006). The $\delta^{13} \mathrm{C}_{\text {carb }}$ and $\delta^{13} \mathrm{C}_{\text {org }}$ data generally record the EACIE similarly, but not always (see e.g. Kaljo in Põldvere, 2003, Martma in Põldvere 2003). In the Ruhnu (500) core from Estonia, a positive excursion is present through the basal $20 \mathrm{~m}$ of the Aeronian Ikla Formation (Martma in Põldvere, 2003), where the key taxon Demirastrites triangulatus occurs throughout (Kaljo in Põldvere, 2003). However, in the Ikla core, also from Estonia, a positive $\delta^{13} \mathrm{C}_{\text {carb }}$ shift in the lowermost Aeronian coincides with a negative $\delta^{13} \mathrm{C}_{\text {org }}$ excursion, see Gouldey et al. (2010) and the graptolite stratigraphy from Kaljo and Vingisaar (1969). From a widely separate palaeobasin, in the Jiaoye-1 core from the Yangtze platform in China, a minor positive $\delta^{13} \mathrm{C}_{\text {org }}$ excursion is noted immediately below the base of the D. triangulatus Biozone in strata assigned to the Rhuddanian (Liu et al., 2017, fig 7). However, this part of the Jiaoye-1 core is biostratigraphically poorly documented. The excursion commences at $2370.2 \mathrm{~m}$, but no biostratigraphically useful graptolites were recorded in the interval $2378.97-2368.97 \mathrm{~m}$ and the lowest Aeronian graptolite documented (Rastrites longispinus at $2368.97 \mathrm{~m}$ ) is not known from the lowermost part of the D. triangulatus Biozone (Štorch et al., 2018; Zalasiewicz et al., 2009). Thus, it appears likely that the excursion in the Jiaoye-1 core commences within the basal Aeronian, rather than in the upper Rhuddanian. Similarly, the commencement of the excursion at Cape Manning, Canada, is poorly constrained where only overlying strata are biostratigraphically assigned (to the D. pectinatus Biozone) (Melchin \& Holmden 2006). Hence, the onset of the excursion may indeed align with the base of the Aeronian, as elsewhere. 
These examples emphasize the value of robust biostratigraphical markers for recognition of, at least the commencement, of the EACIE.

The candidate GSSP section Hlasná Třebaň in the Czech Republic includes the EACIE (as measured in $\delta^{13} \mathrm{C}_{\text {org }}$ ) commencing at the very base of the D. triangulatus Biozone (Štorch et al., 2018). Since the EACIE commences at an identical level also on Bornholm, the base of the $D$. triangulatus Biozone (and Aeronian Stage) may have a very useful chemostratigraphical marker.

\subsection{The tentative presence of the sedgwickii Biozone excursion and the Rumba low}

The significant positive excursion in the S. sedgwickii Biozone as observed at Dob's Linn, Scotland (Melchin and Holmden, 2006), in Arctic Canada (Melchin and Holmden, 2006), Nova Scotia, Canada (Melchin et al., 2014), and Bohemia (Štorch and Frýda, 2012) is not clearly discernible in the Sommerodde-1 core. Indeed, initial analysis of the Sommerodde-1 core samples, which were taken at approximately $1 \mathrm{~m}$ intervals, was complemented by more densely spaced sampling (10 cm intervals) at this level. The complementary samples were taken through the unfossiliferous grey silty mudstones of the lowermost part of log unit F5 (base at $119.4 \mathrm{~m}$, see Figure 2 and Schovsbo et al., 2015) that overlies the highly fossiliferous black mudstones of the Lituigraptus convolutus Biozone (Aeronian), and up into an interval with graptolitic horizons yielding Spirograptus guerichi Biozone taxa (Telychian) at $116.60 \mathrm{~m}$. Three samples have particularly positive values (-28.71\%o, -28.66\%o, and $-29.07 \%$ occurring at $119.37 \mathrm{~m}$, $119.08 \mathrm{~m}$, and $118.92 \mathrm{~m}$, respectively), in the range of peak values observed elsewhere during the S. sedgwickii Biozone (Figure 5). The three positive values occur in a decreasing trend and may be a manifestation of the falling limb, or at least part of, the $S$. sedgwickii Biozone excursion (which in the stratigraphically expanded sequence on Nova Scotia, Canada (Melchin et al., 2014), comprises several separate peaks). Although the presence of an excursion is tentatively suggested, no major positive excursion is observed. The absence of a major 
excursion suggests that the boundary between log units F4 and F5 is an unconformity (Figure 2). The interpreted unconformity in the Sommerodde-1 core spans probably from the Stimulograptus sedgwickii Biozone and possibly also the overlying Stimulograptus halli Biozone (upper Aeronian) (cf. Loydell et al., 2017). These biozones are absent (or unfossiliferous) in the nearby Øleå section (Bjerreskov, 1975) and a thin conglomerate is developed at this level in the Billegrav-2 core (A.T. Nielsen unpublished; see Schovsbo et al. (2015) for location), suggestive of a stratigraphical break. Indeed, the $S$. sedgwickii Biozone is commonly absent in other sequences on Baltica (e.g. Loydell et al., 2010; Walasek et al., 2018).
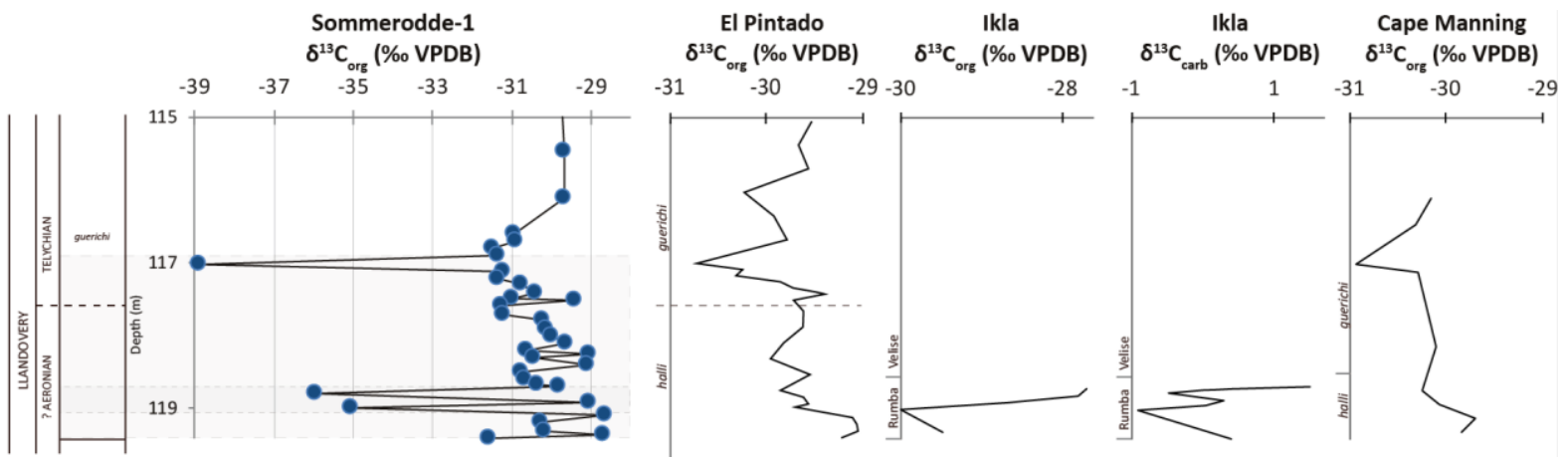

Figure 5. Particularly low values in the uppermost Aeronian and lowermost Telychian marked with pale grey boxes represent the 'Rumba low'. Scale ranges from -28 to -39 \%o. The Sommerodde-1 data are correlated to carbon isotope data described from the El Pintado sections in Spain (Loydell et al., 2015), the Ikla core in Estonia (Gouldey et al., 2010; Kaljo and Martma, 2000), and the sections at Cape Manning in Canada (Melchin and Holmden, 2006). Dashed line marks the presumed boundary between the Aeronian and Telychian.

The densely sampled transition from the Aeronian to the Telychian (119.50 m to 116.60 $\mathrm{m})$ is characterized by generally low $\delta^{13} \mathrm{C}$ values $(\sim 30.9 \% \pm 2.0)$ (Figure 5). Also, in the lower Telychian strata of the Sommerodde- 1 core, two remarkably low $\delta^{13} \mathrm{C}_{\text {org }}$ values, $-35.05 \%$ and $-35.97 \%$, have been recorded at $119.0 \mathrm{~m}$ and $118.8 \mathrm{~m}$, respectively. These two samples derive from the lower part of the unfossiliferous siltstone assigned to log unit F5 (Schovsbo et al., 2015). A single, even lower $\delta^{13} \mathrm{C}_{\text {org value, }}-38.89 \%$, occurs at $117.01 \mathrm{~m}$ (Figure 5). A graptolite sample from 117.14-117.13 m yielded a lower guerichi Biozone assemblage comprising 
Streptograptus pseudoruncinatus, 'Monograptus' gemmatus, and Rastrites maximus (Loydell et al., 2017), which shows that the $117.01 \mathrm{~m} \delta^{13} \mathrm{C}_{\text {org }}$ sample is of earliest Telychian age.A negative $\delta^{13} \mathrm{C}$ excursion has been recorded close to the Aeronian-Telychian boundary in many sections in the Baltic region and elsewhere, in both $\delta^{13} \mathrm{C}_{\text {carb }}$ and $\delta^{13} \mathrm{C}_{\text {org }}$ data (Gouldey et al., 2010). This negative excursion is referred to as the "Rumba low", named after the Rumba Formation in Estonia (Kaljo and Martma, 2000). Walasek et al. (2018) discuss the age of the Rumba low, noting that different authors refer to it as either late Aeronian (Kaljo and Martma, 2000), early Telychian (Gouldey et al., 2010), or straddling the Aeronian-Telychian boundary (Cramer et al., 2011). In the Ikla core, Estonia, the lowest values occur in strata containing Metaclimacograptus hughesi which is a common and widespread species that ranges to the very top of the Aeronian (Loydell et al., 2015) but is not known to extend into the Telychian. Hence, the presence of Me. hughesi strongly suggests a latest Aeronian age of the excursion in Estonia, but in the El Pintado section, Spain, and at Cape Manning on Anticosti Island, Canada, the lowest $\delta^{13} \mathrm{C}_{\text {org }}$ values are demonstrably within the lower guerichi Biozone and thus of early Telychian age (Loydell et al., 2015; Melchin and Holmden, 2006). The Sommerodde-1 core provides additional evidence that the stratigraphically highest and very low $\delta^{13} \mathrm{C}$ value characterizing the Rumba low occurs in the lower Telychian, consistent with the Canadian and El Pintado data. The other two samples with very low values at 119.0 and $118.8 \mathrm{~m}$, i.e. immediately above the unconformity, may theoretically be of latest Aeronian age, which would be consistent with the Ikla core data but this remains uncertain. In any case, considering the Estonian records, the Rumba low appears to straddle the Aeronian-Telychian boundary and represents a useful chemostratigraphical marker for this chronostratigraphical boundary.

No cause has been proposed for the Rumba low as yet. In terms of global environmental changes, the latest Aeronian-earliest Telychian is characterized by rapid sea-level rise (Loydell, 1998), with many localities at this time seeing deposition of graptolitic muds above 
unconformities or shallower water sediments. In this respect, it is noteworthy that low $\delta^{13} \mathrm{C}_{\text {org }}$ values occur both below and above the inferred unconformity in the Sommerodde- 1 core. If the unconformity represents an episode of low sea-level followed by a sea-level rise, it is worthwhile considering whether the mode of early diagenesis may also have shifted. Depending on whether early diagenesis is buffered by seawater (in deep or outboard settings with hemipelagic sedimentation) or sediment (shallow depositional conditions or in the vicinity of restricted platform settings), the isotopic composition may locally change by several permil (plus or minus) in $\delta^{13} \mathrm{C}_{\text {carb }}$ and, subsequently, $\delta^{13} \mathrm{C}_{\text {org }}$ values (Ahm et al., 2018; Higgins et al., 2018). A diagenetic influence could also be indicated by how both the $\delta^{13} C_{\text {org }}$ and $\delta^{13} C_{\text {carb }}$ records of platform settings synchronously demonstrate low values (Oehlert and Swart, 2014). These circumstances make the Rumba low particularly interesting for further explorations of depositional depth, diagenesis and the mix of isotopic signatures.

Other major negative $\delta^{13} \mathrm{C}$ excursions in the Phanerozoic are associated with mass extinctions (e.g. Schoene et al., 2010; Schulte et al., 2010; Shen et al., 2011), but the latest Aeronian-earliest Telychian on the contrary represented a time of dramatic diversification of graptolites (e.g. in Parapetalolithus, Glyptograptus, the retiolitids, Rastrites and Streptograptus; see e.g. Loydell, 1994; Loydell et al., 2015), which makes the Rumba low all the more intriguing. Clearly, the Rumba low warrants more detailed studies.

\subsection{The Valgu positive excursion}

The only manifestation of the Valgu excursion in the Sommerodde- 1 core is from two samples at $90.51 \mathrm{~m}$ and $89.62 \mathrm{~m}$ (Figure 6). At $90.51 \mathrm{~m}$ there is a positive shift of $1.2 \%$ by comparison with the underlying sample at $91.69 \mathrm{~m}$. This level is within the Monoclimacis griestoniensis graptolite Biozone, which correlates with a level in the Pterospathodus eopennatus ssp. n. 2 conodont Biozone (Loydell et al., 2003). In the Viki core, Estonia, peak values of the Valgu excursion occur in the P. eopennatus ssp. n. 2 conodont Biozone (Munnecke and Männick, 2009). Given that there is an excellent sedimentary and biostratigraphical record 
through the lower and middle Telychian in the Sommerodde-1 core, a sedimentary break seems unlikely to explain the lack of a more pronounced Valgu excursion. In the Viki core, the rising

357 limb of the excursion occurs in the P. eopennatus ssp. n. 1 conodont Biozone. This conodont biozone correlates with the upper Spirograptus turriculatus and Streptograptus crispus graptolite biozones (Loydell et al., 1998; Loydell et al., 2003; Männik, 2007a; Walasek et al., 2018). In the S. turriculatus and S. crispus graptolite biozones in the Sommerodde-1 core,

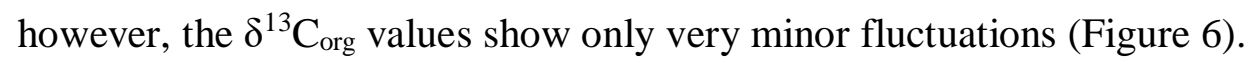

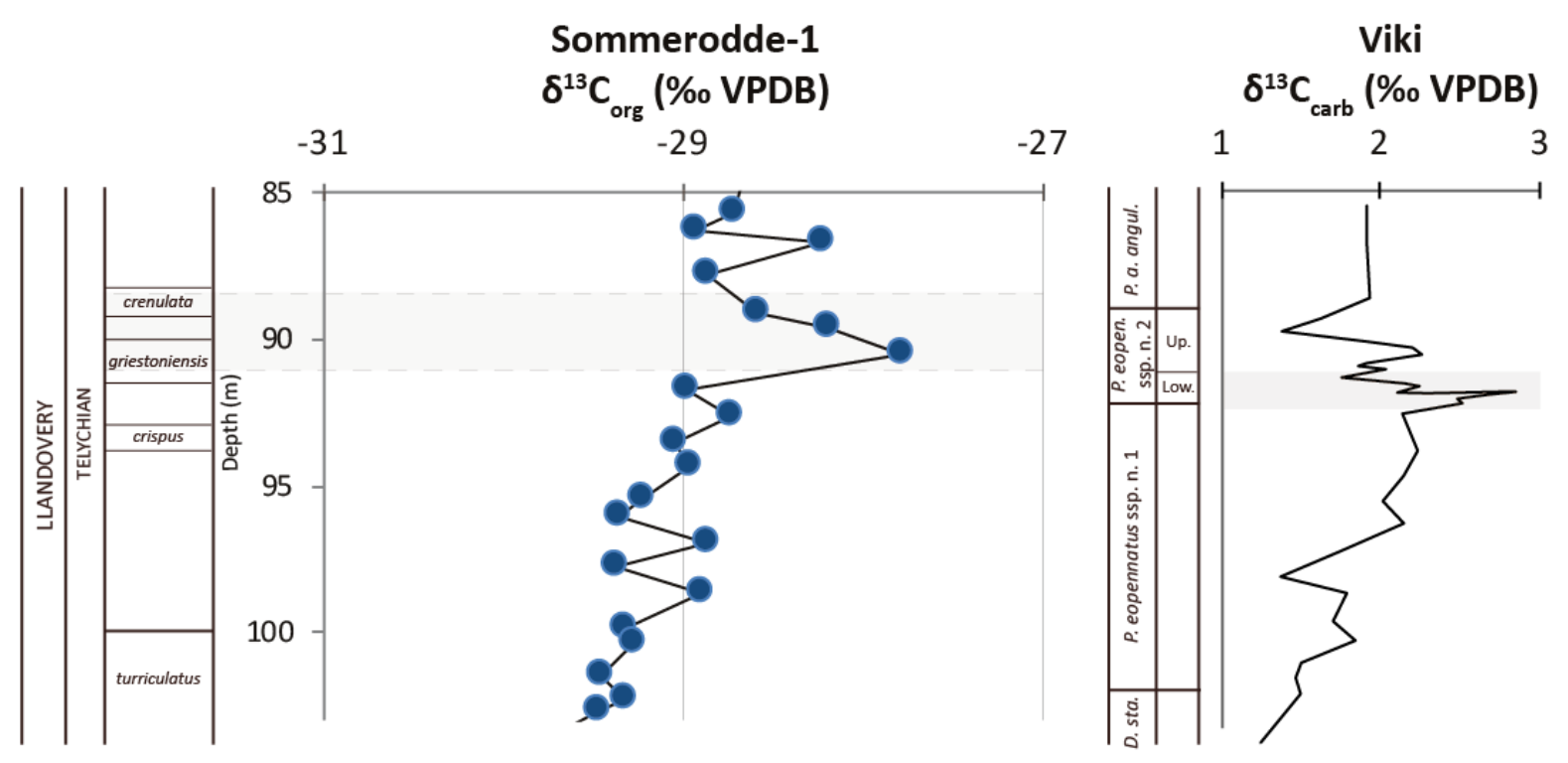

Figure 6. The presumed Valgu positive carbon isotope excursion (grey field, dashed border) in the Sommerodde-1 core (this study). Scale ranges from -27 to -39 \% . In the Viki core, Estonia, the Valgu excursion is apparent in stratigraphically lower strata (Munnecke and Männick, 2009). For correlation between graptolite and conodont biozones, see Männik (2007b).

deposition on southern Bornholm appears continuous through the interval, it emphasizes that we still do not understand why trends in $\delta^{13} \mathrm{C}$ data are often, but not always, reflected in the records of both carbonate and organic carbon, or in shallow but not deep depositional settings. 


\subsection{The new Sommerodde positive isotope excursion (SOCIE)}

The most pronounced positive excursion in the entire Upper Ordovician-Silurian of the Sommerodde- 1 core is seen between $80.55 \mathrm{~m}$ and $70.59 \mathrm{~m}$, extending over several samples within the Oktavites spiralis graptolite Biozone (Telychian) (Figure 7). In this interval, the $\delta^{13} \mathrm{C}_{\text {org }}$ values are significantly higher $(-27.4 \%$ ) than on average for the entire succession ($29.4 \% \pm 1.3)$ and the excursion has an amplitude of $\sim 4 \%$. Peak values are higher $(-25.4 \%$ o than those of both the HICE (-27.7 \%o) and the ESCIE (-27.1\%o). Most of the excursion (77.02 $\mathrm{m}$ to $70.59 \mathrm{~m}$ ) is demonstrably within the middle part of the O. spiralis Biozone (Loydell et al., 2017). We name this new excursion the Sommerodde Carbon Isotope Excursion (SOCIE).

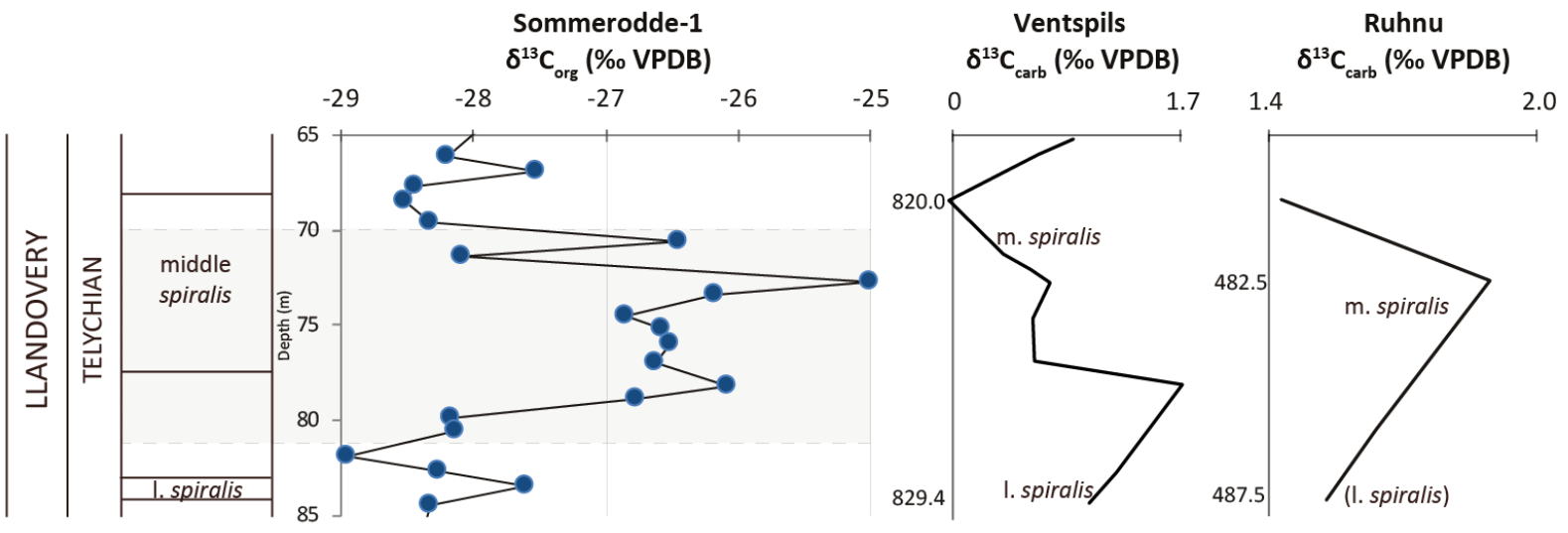

Figure 7. The positive Sommerodde carbon isotope excursion (SOCIE), newly recognized here, in the Oktavites spiralis Biozone. Scale ranges from -25 to $-30 \%$. Indications of a positive excursion may be discerned in $\delta^{13} \mathrm{C}_{\text {carb }}$ data from the Ventspils core in Latvia (Kaljo et al., 1998), and the Ruhnu core in Estonia (Martma in Põldvere, 2003); see also text below and Table 1 for references. The correlations are based on intervals (Sommerodde-1) or levels (Ventspils and Ruhnu) with known biostratigraphical data for the lower (1.), the middle (m.), and the upper (u.) spiralis Biozone ages. In the Ruhnu core, the lower spiralis is assigned by the authors (Kaljo et al., 1998).

The discovery of SOCIE is a surprise considering that compilations of $\delta^{13} \mathrm{C}$ data for the Silurian (e.g. Cramer et al., 2011; Melchin et al., 2012; Sullivan et al., 2018) indicate that the late Llandovery is characterized by a single negative excursion close to the base of the 
Telychian, the Rumba low (see above), and a minor positive excursion, the Valgu excursion (Munnecke and Männick, 2009), in the early-mid Telychian. The remainder of the Telychian is shown as isotopically bland. Thus, the recognition of a second and quite distinct positive excursion within the Telychian highlights the need for great caution when identifying excursions in biostratigraphically poorly constrained sections.

The SOCIE can actually be discerned in previously published isotope curves from the Baltic region. For example, the Ventspils D-3 core from Latvia shows a positive $\delta^{13} C_{\text {carb }}$ excursion of 2-3\%o within the $830-815 \mathrm{~m}$ interval (Kaljo et al., 1998, fig 5). The graptolite biostratigraphy of this part of the core was investigated by Loydell and Nestor (2006) who assigned assemblages from $826.7,821.4$ and $814.0 \mathrm{~m}$ to the lower, middle and upper $O$. spiralis Biozone, respectively. The Ruhnu (500) core from Estonia also shows a small $(<1 \%$ ) positive excursion in $\delta^{13} \mathrm{C}_{\text {carb }}$ at around $480 \mathrm{~m}$ (Martma in Põldvere, 2003). Graptolites from $482.5 \mathrm{~m}$ and $477.65 \mathrm{~m}$ in that core were assigned to the middle and upper $O$. spiralis Biozone,

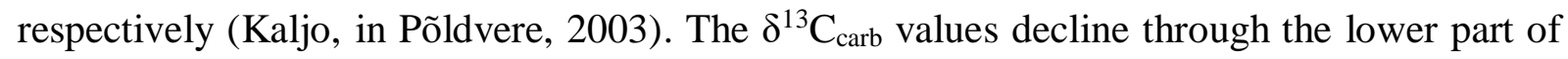
this interval and we infer that it reflects the declining limb of the SOCIE. In contrast, no positive excursion is recognizable in the Viki core from Estonia, where post-Valgu excursion $\delta^{13} \mathrm{C}_{\text {carb }}$ values exhibit only minor fluctuations and an overall gentle negative trend through most of the Telychian (Kaljo et al., 2003). Other Baltic cores (e.g. Ikla; Gouldey et al., 2010) are insufficiently densely sampled or lack sufficient biostratigraphical control to attempt identification of the SOCIE.

The Baltic examples referred to above are all $\delta^{13} \mathrm{C}_{\text {carb }}$ curves, which urges for a cautionary comparison with the Sommerodde- $1 \delta^{13} \mathrm{C}_{\text {org }}$ data. However, since all of the main Silurian excursions discerned so far can be recognized in both $\delta^{13} \mathrm{C}_{\text {carb }}$ and $\delta^{13} \mathrm{C}_{\text {org }}$ records (e.g. Cramer et al., 2011; Melchin and Holmden, 2006; Sullivan et al., 2018), an attempt to identify the SOCIE in published $\delta^{13} \mathrm{C}_{\text {carb }}$ curves is justifiable. In the four $\delta^{13} \mathrm{C}_{\text {carb }}$ records discussed above 
(the Ventspils D-3 core from Latvia and the Ruhnu (500), and Viki core from Estonia), the SOCIE is not recognized in the shallowest setting (in the Viki core; Kaljo et al., 1998; Kaljo et al., 2003). In contrast, the SOCIE is discernible in the Ventspils core, Latvia, which represents the most paleo-offshore site of the four locations discussed. This pattern contrasts with other records of Silurian positive excursions, where the magnitude declines basin-ward (Loydell 2007). Since mixing of isotopic fingerprints in particular is associated with early diagenesis in shallow settings (Ahm et al., 2018; Fanton and Holmden, 2007; Higgins et al., 2018; Holmden et al., 1998), an excursion in the deep Sommerodde-1 setting may serve as a reliable recording of a global perturbation of the carbon cycle.

Outside the Baltic region, published $\delta^{13} \mathrm{C}$ data from the Telychian are limited. Gouldey et al. (2010) show a positive excursion within the Gettel Member of the Laketown Dolostone Formation of the Pancake Range, Nevada, which is of assumed late Telychian age. Unfortunately, the lack of biostratigraphical constraints hinders establishing precise age brackets for this excursion. McAdams et al. (2017), in a study on the lower Silurian of Iowa, show an un-zoned interval bracketed by occurrences of Pt. am. angulatus and Pt. am. amorphognathoides (hence, including strata equivalent in age to the $O$. spiralis Biozone) to exhibit only minor $\delta^{13} \mathrm{C}_{\text {carb }}$ fluctuations and the SOCIE is not identifiable.

Taken together, the newly recognized SOCIE is intriguing in being a distinct positive excursion that has not been widely recognized, and does not seem discernible in the shallow settings in the Baltic basin. The SOCIE appears a suitable candidate for recording perturbations in the global, open-marine setting.

\subsection{The early Sheinwoodian carbon isotope excursion (ESCIE)}

In the early Sheinwoodian, the Sommerodde-1 core data demonstrate a positive excursion of $\sim 2 \%$ that commences between $41.6 \mathrm{~m}(-28.87 \%$ ) and $40.05 \mathrm{~m}(-28.07 \%$ ) (Figure 2). At 
41.05 m, Mediograptus remotus occurs and, at 39.67 m, Euroclimacis adunca occurs (Loydell et al., 2017). While both taxa are typical of the Cyrtograptus murchisoni Biozone, Me. remotus is restricted to the upper part of the biozone whilst $E$. adunca ranges into the overlying Monograptus firmus Biozone (Štorch, 1994b). The biostratigraphical data are thus consistent with the excursion commencing in the upper C. murchisoni Biozone (noting that the immediately overlying strata are biostratigraphically undated). It is in the upper C. murchisoni Biozone that the early Sheinwoodian positive carbon isotope excursion (ESCIE, sometimes referred to as the Ireviken excursion, see discussion in Loydell 2007) has been observed to commence elsewhere (e.g. Cramer et al., 2011; Lehnert et al., 2010; Loydell and Large, 2019). The excursion ends between $32.02 \mathrm{~m}-31.30 \mathrm{~m}$ within strata containing undiagnostic graptolite assemblages, dominated by Pristiograptus dubius and therefore assigned to the Pristiograptus dubius Interval Zone, used by Štorch (1994b) and Zalasiewicz et al. (2009) for strata above the LAD of Monograptus riccartonensis and below the FAD of the upper Sheinwoodian biozonal indices Cyrtograptus rigidus and/or Monograptus belophorus.

The early Sheinwoodian positive carbon isotope excursion (ESCIE) has been the subject of numerous studies, many of which are reviewed by Cramer et al. (2011) and Lehnert et al. (2010). Since these reviews, the excursion has been identified also in the Barrandian area, Czech Republic, by Frýda et al. (2015) and in Poland (e.g. Racki et al., 2012; Smolarek et al., 2017; Sullivan et al., 2018), and a detailed study of the early stages of the excursion has been undertaken on the Buttington section, Wales (Loydell and Large, 2019). In sections with good biostratigraphical control, the ESCIE (with amplitudes varying from 2-4\%o) can be seen to begin high in the Cyrtograptus murchisoni Biozone (Loydell and Frýda, 2007, fig. 4; Loydell and Large, 2019).

Overall, the stratigraphical position and amplitude of this excursion in the Sommerodde-1 core resemble those of the ESCIE as observed globally. 
Our results demonstrate features in the Silurian $\delta^{13} \mathrm{C}$ record that both add to and corroborate previous observations (see Table 1 for an overview).

Table 1. Maximum amplitude (units of \%o) of the carbon isotope excursions discussed

\begin{tabular}{|c|c|c|c|c|c|c|c|c|c|c|c|c|c|c|c|c|}
\hline & \multicolumn{6}{|c|}{ Baltica } & \multicolumn{5}{|c|}{ Laurentia } & \multirow[t]{2}{*}{ W } & \multicolumn{2}{|c|}{ Gond. } & \multirow[t]{2}{*}{ Ya } & \multirow[t]{2}{*}{$\mathrm{Pe}$} \\
\hline & So & $\mathrm{Bi}$ & Es & La & Go & Po & $\mathrm{CP}$ & $\mathrm{CM}$ & NS & PR & $\mathrm{DL}$ & & $\mathrm{Li}$ & Jo & & \\
\hline ESCIE & 2 & & $3^{1}$ & & $2^{2}$ & $4^{3}$ & & & & & & $2^{4}$ & & & & $4^{5}$ \\
\hline SOCIE & 4 & & $1^{6}$ & $3^{6}$ & & & & & & $1^{7}$ & & & & & & \\
\hline Valgu & 1 & & $2^{8}$ & & & & & & & & & & & & & \\
\hline Rumba (-) & 10 & & $3^{9}$ & & & & & & & $1^{7}$ & & & & & & \\
\hline Sedgwickii & 2 & & & & & & & $3^{10}$ & $4^{11}$ & & $3^{10}$ & & & & & $12^{12}$ \\
\hline EACIE & 1 & & $2^{9}$ & & & & & $\mathbf{1}^{10}$ & & & $\mathbf{1}^{10}$ & & & & $1^{13}$ & $1^{14}$ \\
\hline mid-Rhudd. & 1 & & & & & & $2^{10}$ & & & & $\mathbf{1}^{15}$ & & $2^{16}$ & $\mathbf{2}^{17}$ & & \\
\hline HICE & 3 & $4^{18}$ & & & & & & & & & $6^{18}$ & & & & & \\
\hline
\end{tabular}

Carbon isotope excursions discussed here, as recognized on the continents of Baltica (Sommerodde-1 (So), Billegrav-2 (Bi), Estonia (Es), Latvia (La), Gotland (Go), Poland (Po)), Laurentia (Cape Phillips (CP), Cape Manning (CM), Nova Scotia (NS), Pancake Range (PR), Dob's Linn (Scotland)), Avalonia (Wales (W)), and Gondwana (Gond.; Libya (Li), Jordan (Jo)) and on the Yangtze platform (Ya), and Perunica microcontinent (Pe). The studies are referred to in the text when discussing the carbon isotope excursion of the Hirnantian (HICE), the midRhuddanian (mid-Rhud.), the early Aeronian (EACIE), the Sedgwickii Biozone, the Rumba low (Rumba; the only negative excursion), the Valgu, the Sommerodde (SOCIE), and the early Sheinwoodian (ESCIE). The $\delta^{13} \mathrm{C}$ values are measured in organic carbon (bold) or carbonate (normal). Values from this study (So) and from (1) Loydell and Frýda 2007, (2) Munnecke et al., 2003, (3) Sullivan et al., 2018, (4) Loydell and Large 2019, (5) Frýda et al., 2015, (6) Kaljo et al, 1998, (7) Gouldey et al., 2010, (8) Munnecke and Männick 2009, (9) Kaljo and Martma 2000, (10) Melchin and Holmden 2006, (11) Melchin et al., 2014, (12) Štorch and Frýda 2012, (13) Liu et al. 2017, (14) Štorch et al. 2018, (15) Underwood et al. 1997, (16) Loydell et al., 2013, (17) Loydell et al., 2009, (18) Hammarlund et al. 2012.

A surprise in this dataset, is the positive SOCIE excursion. The SOCIE, which spans over $4 \%$, may previously have been recorded in $\delta^{13} \mathrm{C}_{\mathrm{carb}}$ data from palaeo-offshore cores in Estonia and Latvia, but not elsewhere. It is startling that the most significant excursion observed in the Sommerodde-1 core hitherto has remained unrecognized. Indeed, since processes in shallow settings appear to affect the amplification, alteration, and mixing of $\delta^{13} \mathrm{C}$ trends (Fanton and Holmden, 2007; Higgins et al., 2018) an outboard setting with hemipelagic sedimentation that captures a significant positive isotope excursion may have particular value for understanding 
global perturbations of the carbon cycle. Future studies of deep settings outside Baltica may test whether SOCIE represents such a capture.

In contrast, the low $\delta^{13} \mathrm{C}$ values in the Aeronian-Telychian boundary interval including the Rumba low may represent an intriguing anomaly where, possibly, diagenesis has overprinted the primary $\delta^{13} \mathrm{C}$ values. For example, if the low isotope values are associated with shallow depositional settings, the isotopic feature could have captured a local phenomenon involving diagenesis. When early diagenesis of $\delta^{13} \mathrm{C}_{\mathrm{carb}}$ (and then $\delta^{13} \mathrm{C}_{\mathrm{org}}$ ) switches from being buffered by open-marine fluids (deep) to being buffered by fluids from a restricted (shallow) setting, the shift could be accompanied by specific and mixed isotopic signatures (Ahm et al., 2018; Higgins et al., 2018). If the Rumba low has captured a mix of primary and diagenetic carbon isotope signals, it provides an opportunity to decipher the two.

Taken together, both the Rumba low and the SOCIE appear tantalizing study intervals to explore further. These events may provide clues to separate dynamics in the deep versus more shallow settings. With geographically widespread evidence from these events, we can further constrain how, when, and why global climate change occurred, affected, and directed the evolution of animal life during the Ordovician and Silurian periods on Earth.

\section{Conclusions}

The Sommerodde-1 core from Bornholm, Denmark, provides a near-continuous chemostratigraphical archive from the Upper Ordovician through to the Wenlock Series (lower Silurian). A newly recognized positive carbon isotope excursion of $\sim 4 \%$ o in the Telychian Oktavites spiralis Biozone (lower Silurian) is named the Sommerodde Carbon Isotope Excursion (SOCIE). The SOCIE may be particularly valuable since the Sommerodde depositional setting was comparatively deep, where the influence of diagenetic overprint or sealevel change on the $\delta^{13} \mathrm{C}_{\text {org }}$ signal was likely small. The Sommerodde- 1 core section also reflects previously recognized perturbations of the carbon cycle in the Hirnantian (HICE), the early 

of an excursion in the Spirograptus turriculatus and Streptograptus crispus graptolite biozones indicates a need to reassess the Valgu excursion. projects [Grant 2015-5 and 2017-3]. We are grateful for the financial support from the Swedish

\section{References}

Ahm, A.-S.C., Bjerrum, C.J., Blättler, C.L., Swart, P.K. and Higgins, J.A., 2018. Quantifying early marine diagenesis in shallow-water carbonate sediments. Geochimica et Cosmochimica Acta, 236: 140-159.

Ahm, A.-S.C., Bjerrum, C.J. and Hammarlund, E.U., 2017. Disentangling the record of diagenesis, local redox conditions, and global seawater chemistry during the latest Ordovician glaciation. Earth and Planetary Science Letters, 459: 145-156.

Armstrong, H.A., Abbott, G.D., Turner, B.R., Makhlouf, I.M., Muhammad, A.B., Pedentchouk, N. and Peters, H., 2009. Black shale deposition in an Upper Ordovician-Silurian permanently stratified, peri-glacial basin, southern Jordan. Palaeogeography, Palaeoclimatology, Palaeoecology: 368-377.

Armstrong, H.A., Turner, B.R., Makhlouf, I.M., Weedon, G.P., Williams, M., Al Smadi, A. and Abu Salah, A., 2005. Origin, sequence stratigraphy and depositional environment of an Upper Ordovician (Hirnantian) deglacial black shale, Jordan. Palaeogeography, Palaeoclimatology, Palaeoecology, 220: 273-289.

Bjerreskov, M., 1975. Llandoverian and Wenlockian graptolites from Bornholm. Fossils and Strata, 8.

Bjerreskov, M. and Jørgensen, K.Å., 1983. Late Wenlock graptolitebearing tuffaceous sandstone from Bornholm, Denmark. . Bulletin of the Geological Society of Denmark, 31: 129-149.

Calner, M., 2008. Silurian global events - at the tipping point of climate change, Mass Extinction. Springer Berlin Heidelberg, pp. 21-57. 
Calner, M., Ahlberg, P., Lehnert, O. and Erlström, M., 2013. The Lower Palaeozoic of southern Sweden and the Oslo Region, Norway; Field Guide. In: M. Calner, P. Ahlberg, O. Lehnert and M. Erlström (Editors), 3rd Annual Meeting of the IGCP project 591. SGU, Lund.

Cramer, B.D., Brett, C.E., Melchin, M.J., Männik, P., Kleffner, M.A., McLaughlin, P.I., Loydell, D.K., Munnecke, A., Jeppsson, L., Corradini, C., Brunton, F.R. and Saltzman, M.R., 2011. Revised correlation of Silurian Provincial Series of North America with global and regional chronostratigraphic units and $\delta 13 C$ carb chemostratigraphy. Lethaia, 44(2): 185-202.

Díaz-Martínez, E. and Grahn, Y., 2007. Early Silurian glaciation along the western margin of Gondwana (Peru, Bolivia and northern Argentina): Palaeogeographic and geodynamic setting. Palaeogeography Palaeoclimatology Palaeoecology, 245(1-2): 62-81.

Fanton, K.C. and Holmden, C., 2007. Sea-level forcing of carbon isotope excursions in epeiric seas: implications for chemostratigraphy. Canadian Journal of Earth Sciences, 44(6): 807-818.

Frýda, J., Lehnert, O. and Joachimski, M., 2015. First record of the early Sheinwoodian carbon isotope excursion (ESCIE) from the Barrandian area of northwestern peri-Gondwana. Estonian Journal of Earth Sciences, 64: 42-46.

Gouldey, J.C., Saltzman, M.R., Young, S.A. and Kaljo, D., 2010. Strontium and carbon isotope stratigraphy of the Llandovery (Early Silurian): implications for tectonics and weathering. Palaeogeography, Palaeoclimatology, Palaeoecology, 296: 264-275.

Hammarlund, E.U., Dahl, T.W., Harper, D.A.T., Bond, D.P.G., Nielsen, A.T., Bjerrum, C.J., Schovsbo, N.H., Schönlaub, H.P., Zalasiewicz, J.A. and Canfield, D.E., 2012. A sulfidic driver for the endOrdovician mass extinction. Earth and Planetary Science Letters, 331-332C(0): 128-139.

Harper, D.A.T., Hammarlund, E.U. and Rasmussen, C.M.Ø., 2014. End Ordovician extinctions: A coincidence of causes. Gondwana Research, 25(4): 1294-1307.

Heath, R.J., 1998. Palaeoceanographic and Faunal Changes in the Early Silurian, University of Liverpool, Liverpool, $239 \mathrm{pp}$.

Higgins, J.A., Blättler, C.L., Lundstrom, E.A., Santiago-Ramos, D.P., Akhtar, A.A., Crüger Ahm, A.S., Bialik, O., Holmden, C., Bradbury, H., Murray, S.T. and Swart, P.K., 2018. Mineralogy, early marine diagenesis, and the chemistry of shallow-water carbonate sediments. Geochimica et Cosmochimica Acta, 220: 512-534.

Holmden, C., Creaser, R.A., Muehlenbachs, K., Leslie, S.A. and Bergström, S.M., 1998. Isotopic evidence for geochemical decoupling between ancient epeiric seas and bordering oceans: Implications for secular curves. Geology, 26(6): 567-570.

Kaljo, D., Kiipli, T. and Martma, T., 1998. Correlation of carbon isotope events and environmental cyclicity in the East Baltic Silurian. New York State Museum Bulletin, 491: 297-327.

Kaljo, D. and Martma, T., 2000. Carbon isotopic composition of Llandovery rocks (East Baltic Silurian) with environmental interpretation. Proceedings of the Estonian Academy of Sciences, Geology 49: 267-283.

Kaljo, D., Martma, T., Männik, P. and Viira, V., 2003. Implications of Gondwana glaciations in the Baltic late Ordovician and Silurian and a carbon isotopic test of environmental cyclicity. Bulletin de la Société Géologique de France, 174: 59-66.

Kaljo, D. and Vingisaar, P., 1969. On the sequence of the Raikküla Stage in southernmost Estonia. Eesti NSV Teadvste Akadeemia, Toimetised, Keemia Geoloogi, 18: 270-277.

Koren', T. and Bjerreskov, M., 1997. Early Llandovery monograptids from Bornholm and the southern Urals: taxonomy and evolution. Bulletin of the Geological Society of Denmark, 44: 1-43.

Lehnert, O., Männik, P., Joachimski, M.M., Calner, M. and Frýda, J., 2010. Palaeoclimate perturbations before the Sheinwoodian glaciation: a trigger for extinctions during the 'Ireviken Event'. Palaeogeography, Palaeoclimatology, Palaeoecology 296: 320-331.

Liu, Z., Algeo, T.J., Guo, X., Fan, J., Du, X. and Lu, Y., 2017. Paleo-environmental cyclicity in the Early Silurian Yangtze Sea (South China): tectonic or glacio-eustatic control? . Palaeogeography, Palaeoclimatology, Palaeoecology, 466: 59-76.

Loydell, D.K., 1994. Early Telychian changes in graptoloid diversity and sea level. Geological Journal, 29: 355-368. 
Loydell, D.K., 1998. Early Silurian sea-level changes. Geological Magazine, 135(4): 447-471.

Loydell, D.K., 2007. Early Silurian positive $\delta 13 \mathrm{C}$ excursions and their relationship to glaciations, sealevel changes and extinction events. Geological Journal, 42(5): 531-546.

Loydell, D.K., 2012. Graptolite biostratigraphy of the E1-NC174 core, Rhuddanian (lower Llandovery, Silurian), Murzuq Basin (Libya). Bulletin of Geosciences, 87: 651-660.

Loydell, D.K., Butcher, A. and Frýda, J., 2013. The middle Rhuddanian (lower Silurian) 'hot' shale of North Africa and Arabia: An atypical hydrocarbon source rock. Palaeogeography, Palaeoclimatology, Palaeoecology, 386: 233-256.

Loydell, D.K., Butcher, A., Frýda, J., Lüning, S. and Fowler, M., 2009. Lower Silurian "hot shales" in Jordan: a new depositional model. Journal of Petroleum Geology, 32: 261-270.

Loydell, D.K. and Frýda, J., 2007. Carbon isotope stratigraphy of the upper Telychian and lower Sheinwoodian (Llandovery-Wenlock, Silurian) of the Banwy River section, Wales. Geological Magazine 144: 1015-1019.

Loydell, D.K., Frýda, J. and Gutiérrez-Marco, J.C., 2015. The Aeronian/Telychian (Llandovery, Silurian) boundary, with particular reference to sections around the El Pintado reservoir, Seville Province, Spain. Bulletin of Geosciences, 90: 743-794.

Loydell, D.K., Kaljo, D. and Männik, P., 1998. Integrated biostratigraphy of the lower Silurian of the Ohesaare core, Saaremaa, Estonia. Geological Magazine 135: 769-783.

Loydell, D.K. and Large, R.R., 2019. Biotic, geochemical and environmental changes through the early Sheinwoodian (Wenlock, Silurian) carbon isotope excursion (ESCIE), Buttington Quarry, Wales. Palaeogeography, Palaeoclimatology, Palaeoecology, 514: 305-325.

Loydell, D.K., Maletz, J. and Nestor, V., 2003. Integrated biostratigraphy of the lower Silurian of the Aizpute-41 core, Latvia. Geological Magazine, 140: 205-229.

Loydell, D.K. and Nestor, V., 2006. Isolated graptolites from the Telychian (upper Llandovery) of Latvia and Estonia. Palaeontology 49: 585-619.

Loydell, D.K., Nestor, V. and Maletz, J., 2010. Integrated biostratigraphy of the lower Silurian of the Kolka-54 core, Latvia. Geological Magazine, 147: 253-280.

Loydell, D.K., Walasek, N., Schovsbo, N.H. and Nielsen, A.T., 2017. Graptolite biostratigraphy of the lower Silurian of the Sommerodde-1 core, Bornholm, Denmark. Bulletin of the Geological Society of Denmark, 65: 135-160.

Maletz, J., 1997. Ordovician and Silurian strata of the G-14 well (Baltic Sea): graptolite faunas and biostratigraphy. Zeitschrift für Geologische Wissenschaften, 25: 29-39.

McAdams, N.E.B., Bancroft, A.M., Cramer, B.D. and Witzke, B.J., 2017. Integrated carbon isotope and conodont biochemostratigraphy of the Silurian (Aeronian-Telychian) of the east-central lowa Basin, lowa, USA. Newsletters on Stratigraphy, 50: 391-416.

Melchin, M.J. and Holmden, C., 2006. Carbon isotope chemostratigraphy of the Llandovery in Arctic Canada: implications for global correlation and sea-level change. GFF, 128: 173-180.

Melchin, M.J., MacRae, K.-D. and Bullock, P., 2014. A multi-peak organic carbon isotope excursion in the late Aeronian (Llandovery, Silurian): evidence from Arisaig, Nova Scotia, Canada. Palaeoworld, 24: 191-197.

Melchin, M.J., Sadler, P.M. and Cramer, B.D., 2012. The Silurian Period. In: F.M. Gradstein, J.G. Ogg, M.D. Schmitz and G.M. Ogg (Editors), The geologic time scale 2012. Elsevier, Amsterdam, pp. 525-558.

Munnecke, A. and Männick, P., 2009. New biostratigraphic and chemostratigraphic data from the Chicotte Formation (Llandovery, Anticosti Island, Laurentia) compared with the Viki core (Estonia, Baltica). Estonian Journal of Earth Sciences, 58: 159-169.

Männik, P., 2007a. Some comments on Telychian-early Sheinwoodian conodont faunas, events and stratigraphy. Acta Palaeontologica Sinica, 46: 305-310.

Männik, P., 2007b. An updated Telychian (Late Llandovery, Silurian) conodont zonation based on Baltic faunas. Lethaia, 40: 45-60. 
Nielsen, A.T., 2004. Sea-level Changes - a Baltoscandian Perspective. In: B.D. Webby, M.L. Droser, F. Paris and I.G. Percival (Editors), The Great Ordovician Biodiversification Event, Part II. Conspectus of the Ordovician World, Columbia pp. 84-93.

Oehlert, A.M. and Swart, P.K., 2014. Interpreting carbonate and organic carbon isotope covariance in the sedimentary record. Nature Communications, 5: 4672.

Petersen, H.I., Schovsbo, N.H. and Nielsen, A.T., 2013. Reflectance measurements of zooclasts and solid bitumen in Lower Paleozoic shales, southern Scandinavia: Correlation to vitrinite reflectance. International Journal of Coal Geology, 114: 1-18.

Põldvere, A., 2003. Ruhnu (500) drill core. Estonian Geological Sections Bulletin, 5: 1-38.

Racki, G., Baliński, A., Wrona, R., Małkowski, K., Drygany, D. and Szaniawski, H., 2012. Faunal dynamics across the Silurian-Devonian positive isotope excursions (613C, 6180) in Podolia, Ukraine: comparative analysis of the Ireviken and Klonk events. Acta Palaeontologica Polonica, 57: 795832.

Schoene, B., Guex, J., Bartolini, A., Schaltegger, U. and Blackburn, T.J., 2010. Correlating the endTriassic mass extinction and flood basalt volcanism at the 100 ka level. Geology 38: 387-390.

Schovsbo, N.H., A.T., N. and Klitten, K., 2015. The Lower Palaeozoic now fully cored and logged on Bornholm. Geological Survey of Denmark and Greenland Bulletin, 33: 9-12.

Schovsbo, N.H., Nielsen, A.T. and Erlström, M., 2016. Middle-Upper Ordovician and Silurian stratigraphy and basin development in southernmost Scandinavia. Geological Survey of Denmark and Greenland Bulletin, 35: 39-42.

Schulte, P., Alegret, L., Arenillas, I., Arz, J.A., Barton, P.J., Bown, P.R., Bralower, T.J., Christeson, G.L., Claeys, P., Cockell, C.S., Collins, G.S., Deutsch, A., Goldin, T.J., Goto, K., Grajales-Nishimura, J.M., Grieve, R.A.F., Gulick, S.P.S., Johnson, K.R., Kiessling, W., Koeberl, C., Kring, D.A., MacLeod, K.G., Matsui, T., Melosh, J., Montanari, A., Morgan, J.V., Neal, C.R., Nichols, D.J., Norris, R.D., Pierazzo, E., Ravizza, G., Rebolledo-Vieyra, M., Reimold, W.U., Robin, E., Salge, T., Speijer, R.P., Sweet, A.R., Urrutia-Fucugauchi, J., Vajda, V., Whalen, M.T. and Willumsen, P.S., 2010. The Chicxulub Asteroid Impact and Mass Extinction at the Cretaceous-Paleogene Boundary. Science, 327(5970): 1214-1218.

Scotese, C.R., 2001. Atlas of Earth History, Arlington, Texas, pp. 52 Volume 1, Paleogeography, PALEOMAP Project.

Servais, T., Harper, D.A.T., Munnecke, A., Owen, A.W. and Sheehan, P.M., 2009. Understanding the great ordovician biodiversification event (GOBE): influences of paleogeography, paleoclimate, or paleoecology. GSA Today, 4: 4-10.

Shen, S.-z., Crowley, J.L., Wang, Y., Bowring, S.A., Erwin, D.H., Sadler, P.M., Cao, C.-q., Rothman, D.H., Henderson, C.M., Ramezani, J., Zhang, H., Shen, Y., Wang, X.-d., Wang, W., Mu, L., Li, W.-z., Tang, Y.-g., Liu, X.-I., Liu, L.-j., Zeng, Y., Jiang, Y.-f. and Jin, Y.-g., 2011. Calibrating the EndPermian Mass Extinction. Science, 334(6061): 1367-1372.

Smolarek, J., Trela, W., Bond, D.P.G. and Marynowski, L., 2017. Lower Wenlock black shales in the northern Holy Cross Mountains, Poland: sedimentary and geochemical controls on the Ireviken Event in a deep marine setting. Geological Magazine, 154: 247-264.

Štorch, P., 1994a. Graptolite biostratigraphy of the lower Silurian (Llandovery and Wenlock) of Bohemia. Geological Journal, 29: 137-165.

Štorch, P., 1994b. Llandovery-Wenlock boundary beds in the graptolite-rich sequence of the Barrandian area (Bohemia). Journal of the Czech Geological Society, 39: 163-182.

Štorch, P. and Frýda, J., 2012. The late Aeronian graptolite sedgwickii Event, associated positive carbon isotope excursion and facies changes in the Prague Synform (Barrandian area, Bohemia). Geological Magazine, 149: 1089-1106.

Štorch, P., Manda, Š., Tasáryová, Z., Frýda, J., Chadimová, L. and Melchin, M.J., 2018. A proposed new global stratotype for Aeronian Stage of the Silurian System: Hlásná Třebaň section, Czech Republic. Lethaia 51: 357-388. 
Stouge, S., 2004. Ordovician siliciclastics and carbonates of Öland, Sweden. In: A. Munnecke, T. Servais and C. Schulbert (Editors), International Symposium on Early Palaeozoic Palaeogeography and Palaeoclimate. Erlanger geologische Abhandlungen, Erlangen, pp. 91-111.

Sullivan, N.B., Loydell, D.K., Montgomery, P., Molyneux, S., Zalasiewicz, J., Ratcliffe, K.T., Campbell, E., Griffiths, J.D. and Lewis, G., 2018. A record of Late Ordovician to Silurian oceanographic events on the margin of Baltica based on new carbon isotope data, elemental geochemistry, and biostratigraphy from two boreholes in central Poland. Palaeogeography, Palaeoclimatology, Palaeoecology, 490: 95-106.

Underwood, C.J., Crowley, S.F., Marshall, J.D. and Brenchley, P.J., 1997. High-resolution carbon isotope stratigraphy of the basal Silurian stratotype (Dob's Linn, Scotland) and its global correlation. Journal of the Geological Society, 154: 709-718.

Walasek, N., Loydell, D.K., Frýda, J. and Loveridge, R.F., 2018. Integrated graptolite-conodont biostratigraphy and organic carbon chemostratigraphy of the Llandovery of Kallholn quarry, Dalarna, Sweden. Palaeogeography, Palaeoclimatology, Palaeoecology, 508: 1-16.

Veizer, J., 2005. Celestial climate driver: a perspective from four billion years of the carbon cycle. Geoscience Canada, 32: 13-28.

Zalasiewicz, J.A., Taylor, L., Rushton, A.W.A., Loydell, D.K., Rickards, R.B. and Williams, M., 2009. Graptolites in British stratigraphy. Geological Magazine, 146: 785-850. 